\title{
Curie per Milliliter
}

National Cancer Institute

\section{Source}

National Cancer Institute. Curie per Milliliter. NCI Thesaurus. Code C71172.

A unit of volumetric radioactivity concentration defined as a concentration of a

radionuclide with an activity equal to one curie per unit volume equal to one milliliter. 